It includes chapters by 36 American, British and European authors.

The first section consists of articles on the structure, histology and physiology of muscle, their studies of the movements of individual joints, of various types of exercise and finally their application to special diseases and disabilities.

Most articles give necessarily an outline of their subject, while a few are complete monographs, but all are followed by a useful list of references.

\section{BACTERIAL AND MYCOTIC INFECTIONS OF MAN}

Edited by Rene J. Dubos, Ph.D. 3rd edition. Pp. xii +820 , with I 6 illustrations. London: Pitman Medical Publishing Co. Ltd. 1959. $£ 33$ s.

Although the layout of this new edition remains practically unchanged, the individual chapters have been rewritten almost entirely. This extensive revision gives the reader an up-to-date and comprehensive account of medical bacteriology, immunology and mycology. The first seven chapters are concerned with the principles of bacteriology and immunology and these are followed by a systematic treatment of bacterial and mycological pathogens. Each chapter gives a balanced account of the properties of the bacteria, the diseases which they produce, their epidemiology, preventive measures and treatment. Where there have been important new developments relevant experimental data are included. The final chapters of the book are concerned with the principles of sterilization, chemotherapy and epidemiology.

The contributors to this book are all recognized experts in the subjects which they describe and it is of a high standard throughout. It will doubtless be consulted by pathologists and clinicians concerned with the diagnosis and treatment of infectious diseases and will be a valuable addition to the library of both undergraduate and postgraduate students.

\section{THE OESOPHAGUS, MEDICAL AND SURGICAL MANAGEMENT}

By E. B. Benedict, M.D., F.A.C.S. and G. L. NARDI, M.D., F.A.C.S. Pp. 390, with 108 illustrations and 16 colour plates. London: J. \& A. Churchill Ltd. I958. I05s.

In recent years considerable advances have been made in the diagnosis and treatment of oesophageal disease. Furthermore, it must be mentioned that some contribution has been made by the improved technique in radiology and endoscopy.

The efforts of Dr. Benedict and Dr. Nardi to collate our present knowledge of diseases of the oesophagus in the form of a monograph, deserve our attention and respect. By attempting to be concise, however, there is inevitably some loss of detail and style but this is compensated by adequate illustration, some of which is highly coloured.
The authors have sufficient vision to respect the views of others and find space to mention them. To add to these divergences, surely the pulsion diverticulum at the upper end of the oesophagus is in fact pharyngeal in origin. Surely Dohlman's operation is worthy of mention here. These are small criticisms in a useful handbook.

\section{MODERN TREATMENT YEARBOOK, 1959}

Edited by Sir Cecil Wakeley, BT., K.B.E., C.B., LL.D., M.Ch., D.Sc., F.R.C.S. Pp. xix + 312 . London: Baillière, Tindall \& Cox. I959. 30s.

This work has now reached its $25^{\text {th }}$ year of publication and the present volume maintains the high standard of its predecessors. The articles range over all the different branches of medicine, surgery and gynaecology, and are written primarily for general practitioners, but they are sure to be of value to many others. Although it is, perhaps, unfair to select any particular sections from such an interesting variety, those on endocrine crises, migraine, 'the cough that kills,' painful feet and carcinoma of the rectum and colon appear to deserve special mention.

\section{CHILDREN IN PRACTICE}

By John Peterson. Pp. 227. Cambridge University Press. 1959. 25s.

Most teachers of medical students now realise that they should not only teach " hospital medicine," but also give the student more than a superficial acquaintance with the impact of environment on the health of the individual.

'Social work' and 'almoning' are not always popular subjects with the student, not merely because a knowledge of them is unlikely to help him in passing his examinations, but also because their relevance is at variance with the concept that ' laboratory medicine' and 'science' will provide the answers to the patient's illness.

The writer of this book, Warden of University House, Bethnal Green, not a doctor, records his attempts to interest medical students in social questions and he has been given the chance to do so while the students are studying paediatrics. This made his task particularly easy.

We know, however, that there are still some medical schools where this side of the future general practitioners' work is not taught: students from such places ought to read this work. Others, too, will find it useful, as there are details of the social services available to help children who have specific handicaps.

\section{A SYSTEM OF ORTHOPAEDICS AND FRACTURES}

By A. Graham Apley, M.B., B.S., F.R.C.S. First Edition. Pp. vii, 357 and 20. London: 